\title{
EFFECT OF THE TIME OF INTRODUCTION OF COMPONENT CROPS AND OF FERTILIZER-N APPLICATION ON MAIZE AND VEGETABLE COWPEA GROWN IN MIXTURES UNDER THE HUMID TROPICAL CONDITIONS
}

\author{
D. A. Okpara \\ College of Crop and Soil Sciences \\ Michael Okpara University of Agricullure, Umurlike
}

\begin{abstract}
Field experiments were carried out during 1998 and 1999 cropping seasons at Umudike, south eastern Nigeria, to evaluate the yield performance of maize intercropped with vegetable cowpea under different planting schedules. Treatments comprised vegetable cowpea planted 4 weeks before, same day as, 4 and 8 weeks after maize and nitrogen levels of 0,50 and $100 \mathrm{kgN} / \mathrm{ha}$.

The results showed that plant height, leaf area index, dry matter and pod yield in vegetable cowpea as well as seed yield in maize decreased significantly following delay in the introduction of either crop in mixture. Usually the component crop that was planted earlier in the mixture gave a stiffer competition against the componem that was planted later as demonstrated by growth and yiele valines. Conses of applled $N$ increased growth and ytelds in the intererops. On the average, plaming vegetable cowpea at 4 weeks before, same day as, 4 and 8 weeks afier maize gave yield advantages of 98,93, 64 and 97\% respectively, over sole cropping. The yield advantages due to incercroping at 0,50 and $100 \mathrm{kgN} / \mathrm{ha}$ were 131,81 and $74 \%$ respectively. Planting the mixture the same day produced more satisfactory yields of the intercrops that other planting schedules while fertilizer use was optimized by applying $50 \mathrm{~kg} \mathrm{N/ha.}$
\end{abstract}

Key words: Maize, Vegetable cowpea, Mixture, Time of introduction, Fertilizer $N$, Land equivalent ratio.

\section{INTRODUCTION}

Intercropping maize (Zea mays) and vegetable cowpea (Vigna unquiculata sub species sesquipedalis) provides one of the common crop combinations in the intercrop system adopted by local farmers in the forest zone of south eastern Nigeria. While maize is grown through out the country, vegetable cowpea is restricted, in cultivation and use, to the derived savannah and forest belts (Uguru, 1996). The produce from both crops contributes substantially to the dietary carbohydrates and proteins of the rural populace during one half of the yent, from May to October (U7,n, 1983).

Modifications in time, technicue and pattern of planting crops grown in association can enhance the compatibility of mixtures and make intercropping a more feasible practice (Singh and Anyaneyulu, 1979). A combination of tall and short crops gave a good performance, especially if the tall crop was planted a little later (Crookston and Kent, 1976). In the traditional farming systems of the tropics, the component crops may be sown at the same or different times, depending on the farmers preference (Remison, 1982; Ofori and Sterm, 1987). Rescarch information is scanty on the competition between maize and vegetable cowpen in mixture. Information is also limited on the fertilizer needs of the maize and vegetable cowpea intercrops in the 
7one. Nitrogen is oflen in short stupply for most crops grown in the area, especially beenuse oflenching fion high rainfall and the sandy nature and low organic matter content of the soil (Asiegbu, 1989). As maize is a high nittogent-demanding crop, there may be need to augment the nitrogen supply from the vegetable cowpea with inorganic nitrogen fertilizer. The vegetable cowpea may also require some fertilizer nitrogen especially for early growth.

The objectives of this paper were to examine the effects of time of introducing vegetable cowpea into maize/cowpea mixtures, and the effects of nitrogen fertilizer on maize/ vegetable cowpea intercrops in the forest zone of south eastern Nigeria.

\section{MATERIALS AND METHODS}

The experiment was conducted in 1998 Inid repenled In 1999 at the Research Farm of the Michnel Okpara University of $\triangle$ griculture. Umudike, south eastern Nigeria. Umudike lies on Latitude $5^{\circ} 28^{\prime} \mathrm{N}$, Longitude $7^{\circ} 33^{\prime} \mathrm{l}$ and at altitude $122 \mathrm{~m}$ above sea level. The total rainfall at Umudike during the study period (March to October) were $1901.0 \mathrm{~mm}$ in 1998 and $2507.2 \mathrm{~mm}$ in 1999. The soil of the location was characterized as sandy loam ultisol.
In the first year (1998), a $3 \times 3$ factorial experiment in randomised complele block design with three replications was used. The lactors consisted of three periods of introducing vegetable cowpea of same day as maize (May 14), 4 weeks after planting maize (June 11) and 8 weeks after planting maize (July 9) and three nitrogen levels of 0,50 and $100 \mathrm{~kg} /$ ha). In 1999, a 4 ×3 factorial experiment was conducted. There were four periods of vegetable cowpea introduction of 4 weeks before planting maize (April 17), same day as maize (May 14), 4 weeks after maize (June 11) and 8 weeks after maize (July 9). 'The three nitrogen levels were 0,50 and $100 \mathrm{~kg} /$ ha as urea. Each plot measured $4 \mathrm{~m} \times 4 \mathrm{~m}$.

Land previously planted to cassava but under a one year fallow at the commencement of the experiment, was disc ploughed, harrowed and rigded $1 \mathrm{~m}$ apart. FARZ-23-yellow and a local vegetable cowpea variety, Isuochi Black, were used. 'The crops were hand sown nl two seeds per hole and later thinned down to one plant per stand two weeks a fler planting (WAI'). $\Lambda$ spacing of $1 \mathrm{~m} \times 0.25 \mathrm{~m}$ and a density of 40,000 plants/ha were maintained for each crop. Maize occupied one-half of the ridges while vegetable cowpea occupied the second-half. Sole crops of maize and vegetable cowpea were included to ensure computation of land equivalent ratio (LER). Each plot was given blanket application of $40 \mathrm{kgP}_{2} \mathrm{O}_{5}$ and $40 \mathrm{kgK}_{2} 0$ per hectare as single super phos-

Iable 1: Soil and rainfall data of the site during the experimental periods

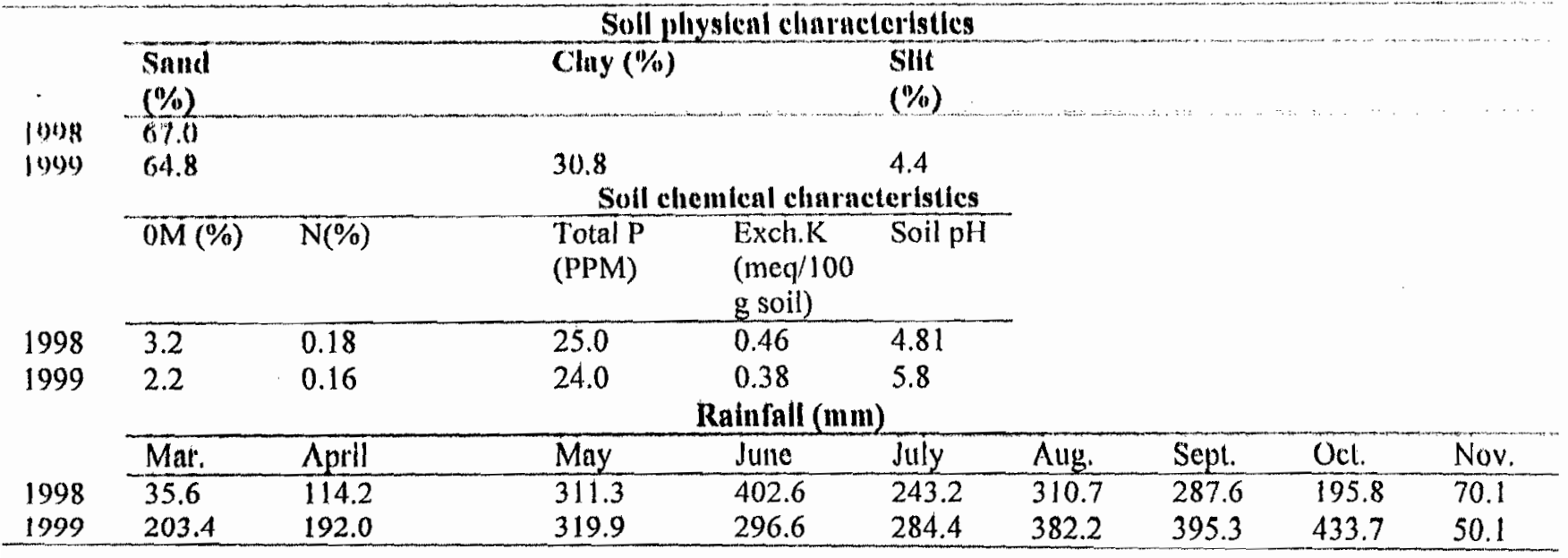


T'able 2: Effect of time of introducing vegelable cowpen and cowpen and nitrogen fertilizer on growth of the component crops at 7 WAP in 1998

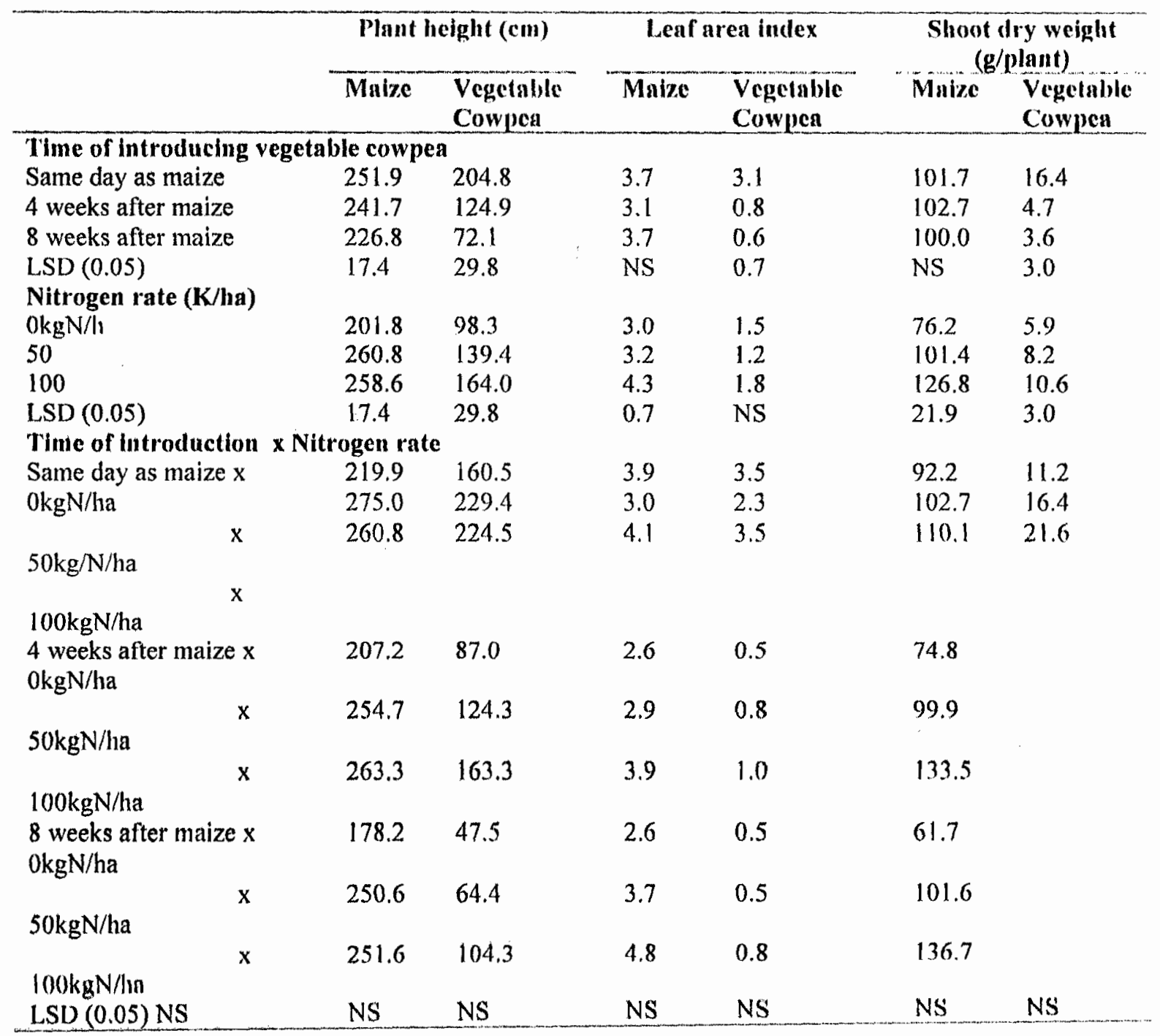


Table 3: Effect of time of introducing vegetable cowpea and nitrogen on yield and yield components of maize

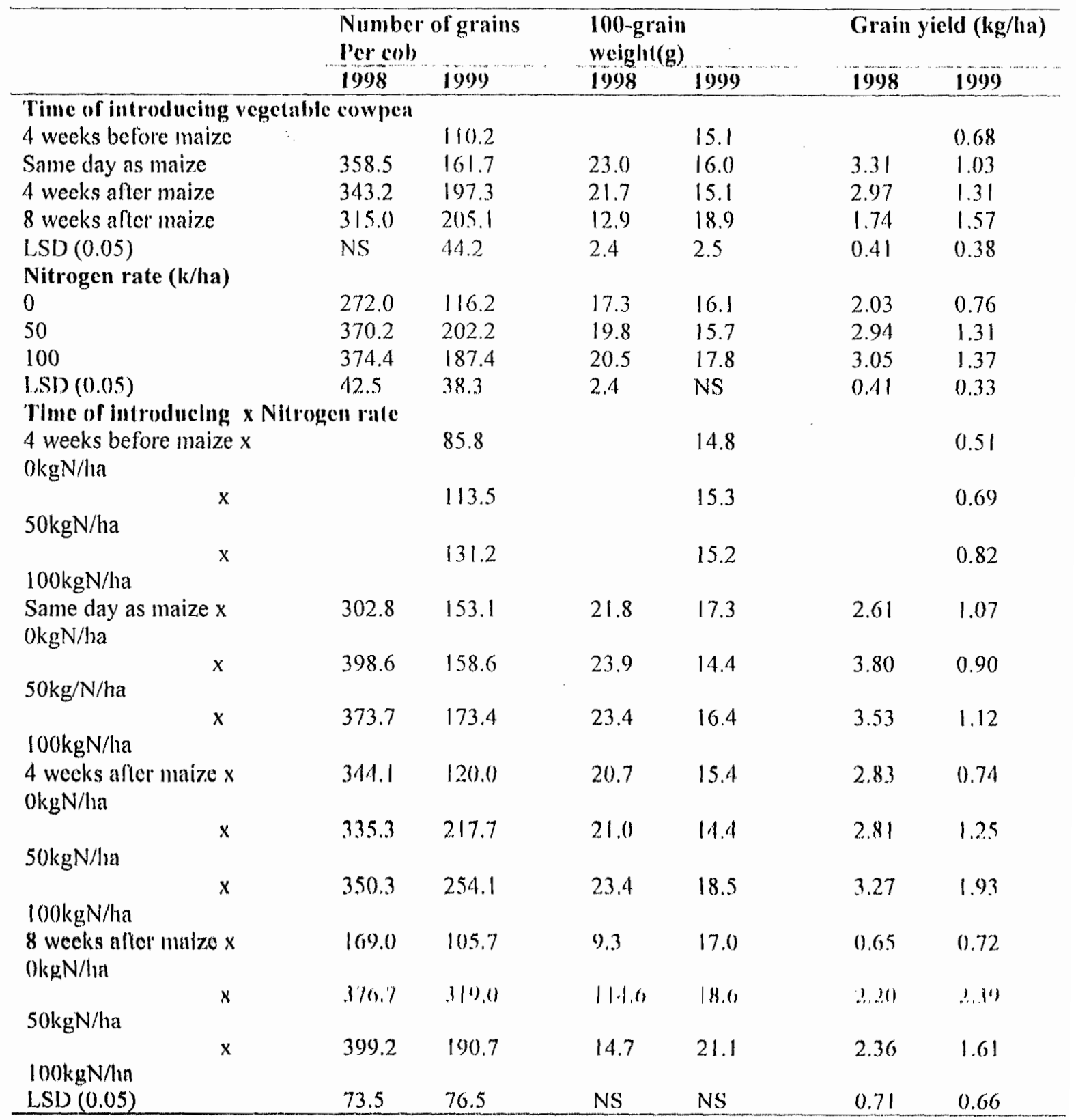


phate and inuriate of potash respectively. The

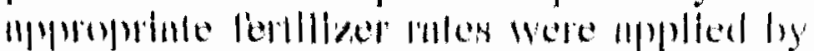
banding one week after planting maize. Plots were hoe-weeded three times at 3-week intervals afler sowing the first crop, sprayed thrice with karate at $100 \mathrm{ml}$ in $20 \mathrm{~L}$, water at 3 . week intervals alter sowing to proted them against insect pests.

Data were collected on plant height, leal area index and shoot dry weight in 1998 only. Data on number of pods/plant, pod weight (g), pod yield (kg/ha), number of seeds/pod and cob), 100-seed weight (g) and seed yicld (kg/ ha) were obtained in 1998 and 1999. Leaf arca of maize was determined using Elsaliookie's (1977) formula while that of vegetable cowpea was computed with the formula by OseiYeboah et al (1983). Data obtained were stalistically analysed using the procedures of Steele and forrie (1980) for randomised complete block design (RCIBD). L and ecpuivalent ratio and competition coefficient (C) were calculated using the formulae of Fisher (1977) and Okigbo (1979) respectively.

\section{RESULTS}

Delay in introducing vegetable cowpea in maize significantly reduced plant height in both crops, and, also depressed the leaf area index and dry weigh of shoot in vegetable cowpea al 7WAP' (Table 2). Nitrogen fertilizer application at $100 \mathrm{kgN} / \mathrm{ha}$ significantly increased height and dry malter accumulation in maize and vegetable cowpea. Interaction of time of introducing vegetable cowpea $x$ nitrogen did not significantly affect the growth attributes at $7 \mathrm{WAP}$.

Maize grain yields were, on the averige, signficantly grealer where the mixture was planted the same day or vegetable cowpea was introduced 4 weeks after maize compared with where vegetable cowpea was introduced 4 weeks before or 8 weeks after maize (Table 3). Nitrogen fertilizer application increased seed yields significantly compared with where no $\mathrm{N}$ fertilizer was applied.

The highest maize grain yields occurred where the mixture was planted the same day or where vegetable cowpea was introduced 4 and 8 weeks after maize and nitrogen applied at 50 or $100 \mathrm{kgN} / \mathrm{ha}$ while the least yield oc- curred where vegetable cowpea wis planted 4

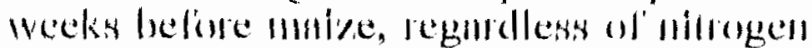
levels applied. Maize grain yields in 1998 were much higher than in 1909.

On the other hand, vegetable cowpea pod yields were significently greater when the crop was planted 4 weeks before maize than when the mixture was planted the same day or where vegetable cowpea was introduced 4 or 8 weeks after maize (Table 4). Planting the mixture the same day gave a signilicantly highor pod yick then planting maize calllier and introducing vegetable cowpea later. Successive increments in the rate of nitrogen fertilizer application significantly increased pod yeilds within the range of fertilizer used. Seed yield and number of pods/plant were similarly increased by nitrogen application. Interaction of time of introducing vegetable cowpea and nitrogen on pod yicld was signilicam in 1999), The greatest pod yields were obtained where vegetable cowpea was planted 4 weeks before maize and sitrogen was applied at $100 \mathrm{kgN} / \mathrm{ha}$, while the least pod yicld occurred where vegetable cowpea was planted 8 weeks after maize, regardless of nitrogen levels applied.

Except for where vegetable cowpea was introduced at 4 weeks after maize, the land equivalent ratios were similar for all planting schedules (Table 5). 'The advantages of intercropping were 131,81 and $74 \%$ for the 0,50 and $100 \mathrm{kgN} / \mathrm{ha}$ treatments, respectively. Maize had compctition coellicient greater than 0.5 where both crops were planted the same day or where the vegetable cowpca was introduced at 4 weeks after maize and nitrogen applied at 0 or $50 \mathrm{kgN} / \mathrm{ha}$ in 1998. In 1999, however, competition coefricient was in favour of maize $(\mathrm{C}>0.5)$ where vegetable cowpea was introduced at 4 and 8 weeks after maize and nitrogen was applied at $100 \mathrm{kgN} / \mathrm{ha}$.

Competition coeflicient favoured vegetable cowpea in cases where the crop was introduced 8 weeks after maize in 1998 and where the mixture was planted the same day or where vegetable cowpea was planted 4 weeks before maize in 1999, regardless of the nitrogen levels. 


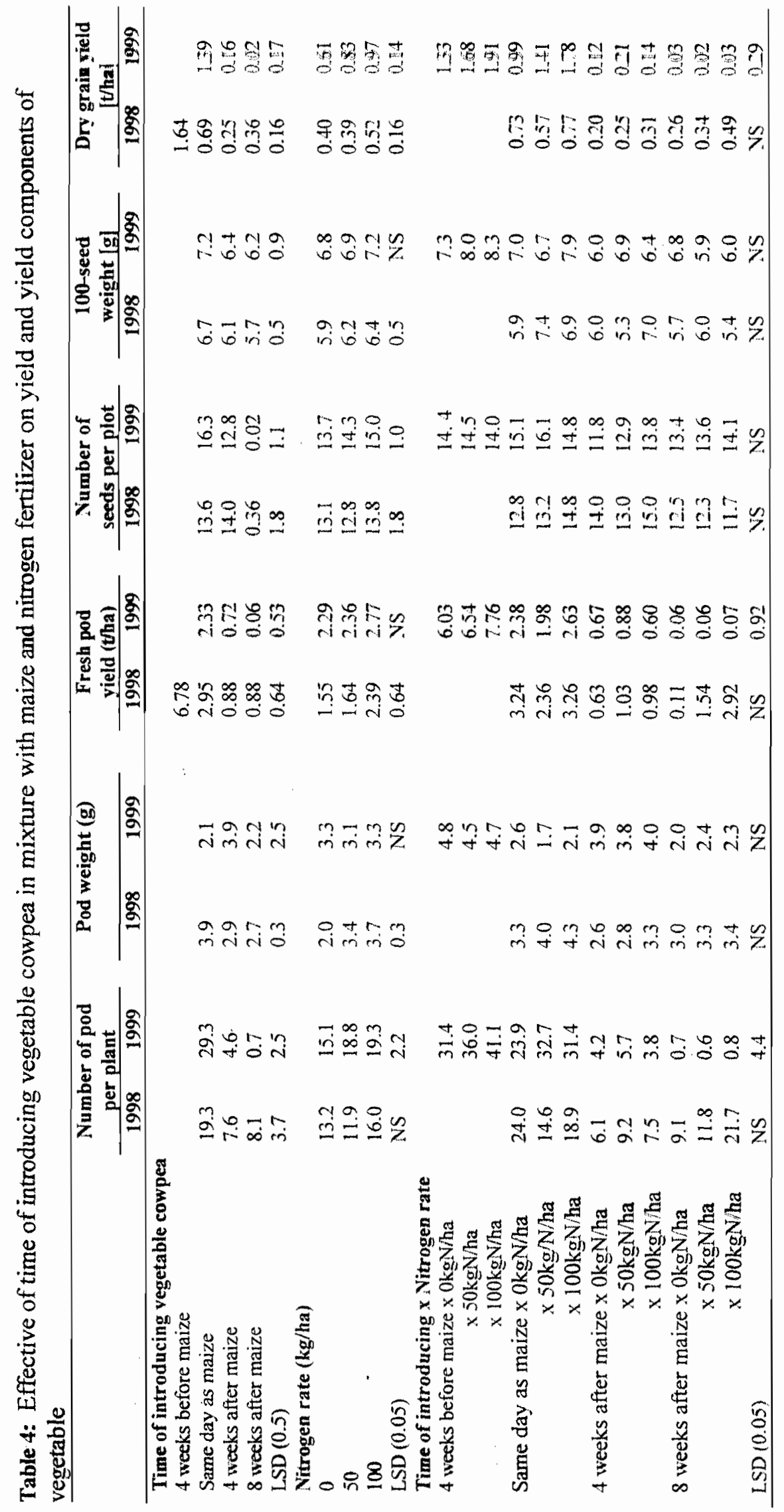




\section{DISCUSSION}

Introducing vegetmble convpen 1 or 8 weeks after maize had been planted resulted in signilicant reductions in lieight, leal area index and dry matter in the vegetable cowpea, compared with where the mixture was planted the same day. In the study reported here, maize was taller and produced more leaf area and was therefore at an advantage over vegetable cowpea. The general conclusion from experiments involving competition for light is that the component with its leaf area higher in the canopy is at an advantage (Stern and Donald, 1962; Donald, 1963; Remison, 1982; Adelana, 1981; Muoneke et al, 1997).

This study showed that the yield of each component of the mixture decreased when sorvin later than the other component. Ofori and Stern (1987) and Remison (1982) had similarly observed that when component erops in mixture were sown at different times, the carlier sown component often had an initial competitive advantage over the later one. On the average, maize grain yields were depressed by $69 \%$ when maize was sown 4 weeks after planting vegetable cowpea while pod yields in vegetable cowpea were reduced by 70 and $82 \%$ when it was introduced into maize plots 4 and 8 weeks after, respectively compared to where the mixture was planted at the same time. Planting maize 4 weeks after vegetable cowpea seemed undesirable not only because the desired protein-energy balance as given by May (1982) may not be achieved but also heeause maize seedlings stand very high risk of being smothered by the trailing vegetable cowpea vines. For the soil of this investigation, nitrogen fertilizer application at $50 \mathrm{kgN} / \mathrm{ha}$ appeared satisfactory for achieving high yields of maize and vegetable cowpea in mixture. Results did not show any evidence that higher fertilization could be utilized to advantage in the planting schedules. The yields of both crops illustrate the trade-off that occurred between maize and vegetable cowpea. The yield of each crop decreased as the competitiveness of the other crop increased, a finding that is corroborated by oller observations (Willey, 1979; Freyman and Venkaleswarly, 1979; May, 1982). Increasing eompetilive ability of maime consistently depressed vegetable cowpea yields and number of pods/plant while increasing competitive ability of vegetable cowpea was evident in depressing the grain yield of maize.

The mixtures had, on the average, land equivalent ratios above 1.0 , indicating that higher productivity per unit area was achieved by intercropping maize with vegetable cowpea than by growing either of the two crops separately. Although the land equivalent ratios for the 50 and $100 \mathrm{kgN} /$ ha treatments were lower than the zero nitrogen treatment, the total absolute yield was, in most cases, far greater in the 50 and $100 \mathrm{kgN} /$ ha treatments dhen where no lichlilizer $N$ wass applied. Yickls were much lower for maize in 1999, probably owing to heavicr rainlall which might have caused leaching of nutrients, water logging of some plots and cloud cover. Indoubtedly, maize, a C4-plant characterized by high efficiency of light utilization (Uzo, 1983) was more disadvantaged photosynthetically under the cool, dull conditions of the 1999 cropping season. Milthorpe and Moorby (1975) had reported that $\mathrm{C}_{3}$-species have a photosynthetic advantage over $\mathrm{C}_{4}$-species under cool, dull conditions.

\section{CONCLUSION}

The results indicated that maize and vegclable cowpea can be sucecssfilly intercropped. From overall consideration of the yield values, it is concluded that fertilizer use can be optimized by applying $50 \mathrm{kgN} / \mathrm{ha}$. Planting the mixture the same day not only gave higher LER values but also produced more satisfactory yields of the intercrops than the other planting schedules, which drastically reduced the yields of either the maize or vegetable cowpea component. 


\section{REFERENCES}

Adelmm, B. O. (1984). Evaluation of maizetomalo mixed cropping in Soulli-westem Nigerla. India J. Agric. Sci. 564-9.

Asicghu, J. 1..(1989). Response of onion lo time and restilizer $N$ in a lropical Ultisol. Tropical Agric. 66(2): 161.

Crookston, R. K. and Kent, R. (1976). Intercropping: $A$ new version of an old idea. Crop and Soils 28(2): 7-9.

Donald, D. M. (1963). Competition among crop and pasture plants. $\Lambda$ dv. $\Lambda$ gron. 15:1-18.

Filsahookie, M. M. (1977). $\Lambda$ new formula to estimate leaf area in corn (Zea mays 1.). plant Breeding $\Lambda$ bstract (1978). 48: 1196.

lishlıe, N. M. (1977). Studies in mixed cropping. Seasonal difference in relative productivity of crop mixlures and pure stands in the Konya highlands. Jixp. Agric. 13:187-191.

Freyman, S. and VenKateswarlu, J. (1977). Intercropping on the rainfed red soils of the Deccan Plateau, India. Canadian Journal of Plant Sci. 57: 697-705.

IJunt, R. (1978). Plant Growth Analysis. Studies in Biology. No. 96. Edward Amold (Publishers) Limited, London.

May, K. W. (1982). Elrect ol planting schedules and intereroppling on green gram

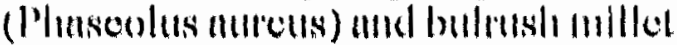

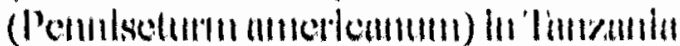
ixp. Agtic. 18:149-156.

Millienre, 1i. I. and Moorby, J. (1975). An Introduction to crop physiology. Cambridge University Press, liondon. Pp:82-85.

Mouneke, C. O.; Asiegbu, J. Ea and Udeogalanya, A. C. C. (1997). Efrect of relative sowing time on the growh and yield of the component crops in okro/maize and okro/cowpea inter- cropping systems. J, Agronomy and Crop Science. 179: 179-185.

Olori, O. and Stern, W. R. (1987). Relative sowing lime mel densily of eompenent crops in a maize/cowpea intereropping systeill. Lixp. Agrice, 23:4 1-52.

(okigbo, B. N. (1979). Lvaluation of plant interactions and productivity in complex mixtures as a basis for improved cropping systems design. In: Proceding of International Workshop on Intercropping. Ilyderabad, India. 10-13 Jan. 1979. Pp. 155-179.

Osei-Yeboah, S; Lindsay, I. I and gumbs, F.H. (1983). Fstimating leaf area of cowpea (Vigna unguiculata 1 . Walp) for linear measurements of terminal leaflets. Tropical Agric, 60): 149-150.

Remisen, S. U. (1982). Interaction between maize and the cowpea sown simultaneously and at interval in a forest zone in Nigeria. India Joumal $\Lambda$ gric. Sci. 52: 500-505.

Steele, (j. D. and 'lorric, J. II. (1980). Principles and procedures of statisties: A Biometrical Approach. 2 $2^{\text {nd }}$ Edition MeGraw Hill Book company Inc., New York.

Stern, W. R. and Donal, C. M. (1962). Light relationships in grass clover sward. Asutria joumal Agriculural Research. 13:599-614.

Iguru. M. I. (19)(6). A note on llue Nigerim vegetable cowpen. (ienetic Resontes and Crop livolution. 43:125-128.

(120, J. (). (198.3). Mixed eropping of yom, 'fellitulu, matre and okra lin a compoumal larming system of South eastern $\mathrm{Ni}$ geria. Acta liorticulturne. 123:305315 .

Westernann, D. T. Kleainfopt. G. E; Porter, 1. K. and Legaett, G. E. (1981). Nitrogen sources for bean seed production. Agron. J. 73: 600-664. 
Willey, R. W. (1979). Intercropping-its inportance and its research needs. P'art 1 competition and yield advantages. Part 11 Agronomic relationships lick Crop Abstract. 32:1-10, 73-85 